\title{
Characters and characterization in John Lyly's Endymion: The Man in the Moone
}

\author{
Mufeed Al-Abdullah
}

Associate Professor, Jerash University, Jordan

Received: 28 Mar 2021; Received in revised form: 01 May 2021; Accepted: 16 May 2021; Available online: 12 Jun 2021 (C)2021 The Author(s). Published by Infogain Publication. This is an open access article under the CC BY license (https://creativecommons.org/licenses/by/4.0/).

\begin{abstract}
This paper studies the characters and the methods of characterization John Lyly uses in his euphuistic court play Endymion: The Man in the Moon (1591). The characters gather mythological, allegorical, and historical significance and are arranged in a hierarchy from the moon down to earth. The techniques the writer uses include the traditional methods of characterization through speech and action. And since the events in the play do not reach the level of a plot in the Aristotelian definition, which prevailed in the Renaissance, the writer underplays the method of character depiction through action. He, however,gives a lot of attention to portraying the characters through their utterance. This results from the fact that the characters spend most of the time talking about their attitudes, their relationships, and the few events that take place in the play. Lyly also uses the less traditional method of juxtaposition and social positioning. Juxtaposition is generated from the binary nature of Endymion and the crowd of antithetical pairs of characters that populate the drama. The social positioning method of character portrayal places the characters in a stratified social, allegorical, and mythical structure from which they gather various collective attributes by belonging to the given layers in the formatted structure. The article means to shed light on Lyly's dramaturgy by studying these means of character depiction.
\end{abstract}

Keywords-Endymion, myth, characterization, juxtaposition, social positioning, binary, antithetical.

\section{INTRODUCTION}

John Lyly (1554-1606), who was one of the University Wits in the Elizabethan age, was first acknowledged for the two euphuistic novels, Euphues: The Anatomy of Wit (1578) and Euphues and His England (1580),which secured him recognition as a prose stylist. Later he devoted himself to writing court comedies. These comedies include Campaspe (1583), Sapho and Phao (1583), Gallathea (1585), Endymion (1588), Midas (1589), Love's Metamorphosis(1590), Mother Bombie (1590), and The Woman in the Moon (1595). With the exception of the last play which was written in blank verse, all Lyly's comedies are in prose. Among all the works, Endymion: The Man in the Moone (1591) is considered the most characteristic of John Lyly's court plays.Like all Lyly's plays, it was performed at court to entertain Queen Elizabeth I and her train. However, Endymion goes beyond the aim of entertainment to flatter the queen (Saccio, 2016, 173; and
Bryant, 1956, 4-12, 6). Saccio, however, focuses in his analysis of the playon both the moral and political allegory built into its complex dramatic structure. Joseph Bryant interprets the play as a personal allegory for Lyly's own relation to the queen, and thus the play can serve as a compliment to her:

We had better look for an interpretation that has to do with Lyly's own relation to the queen: his long disappointed hopes for preferment, the shadowy difficulties of 1594 , his renewed hope after the intervention of a friend, and his need to express to his sovereign his confidence that hereafter she would recognize his unswerving devotion to her (10).

Bryant's explanation refers to Lyly's attempts to get a position in the Office of Master of the Revels. Along the same lines,G. K. Hunter (1962) analyzes the plays of Lyly, 
especially Endymion, as an effort of the playwright to advance himself in the court. Similarly, Natalia Khomenko (2010) gives the allegory an autobiographical meaning to explain it as a "panegyric" (p. 56) for the queen in the hope to be appointed the Master of the Revels, a position that he was never granted to him despite his appeals for it. This interpretation takes a clue from the Epilogue of the play: "But if Your Highness vouchsafe with your favorable beams to glance upon us, we shall not only stoop, but with all humility lay both our hands and hearts at Your Majesty's feet" (13-14) [Khomenko, 2010, p. 37].

As Lyly chose the myth of Endymion's love for the Moon to distance the audience, he simultaneously engaged them in contemporaneous historical events in the royal court of England and contemporary debates about issues like magic and witchcraft (Khomenko, 2010, p. 37). Thus, she finds in the play a platform for the Elizabethan debate on witchcraft and sorcery. Furthermore, Khomenko (2010) juxtaposes Cynthia's healing power with Dipsas' disruptive power. She further argues that the play points out the quest for the elision of witchcraft and women who use it even for healing, which gives sorceresses divine abilities (p. 38).

Early accounts of George Baker (1894) and E. F. Schelling (1910), however, interpret the play as a political allegory with Elizabeth as Cynthia, the Earl of Leicester as Endymion, and Leister's two living wives, Lady Sheffield and Lady Essex, as Tellus and Floscula, respectively. These critics assert that the play is an apology for Leicester's secret marriage to Lady Sheffield. According to these studies, Endymion's sleep is interpreted as the period of Leicester's estrangement from the court of Elizabeth I. Accordingly, the play is interpreted as sycophancy to the queen for her merciful nature and her clemency and forgiveness of Leicester represented by her symbolic and healing kiss of Endymion.

Peter Weltner (1973) analyzes the play symbolically on the basis of Jungian archetypes, thus ignoring the previous interpretations that are based on historical events in the Elizabethan age. Robert Knapp (1976) argues that Lyly deliberately makes the play enigmatic in order to make possible the various interpretations of the allegory of love. Carolyn Ruth Lenz (1976) in her elaborate article "The Allegory of Wisdom in Lyly's Endymion" interprets the allegory within the context of sixteenth-century notions of Neo-Platonic love.

Whatever the differences among the critics in identifying the characters of the play with real persons during Lyly's time, there is one thing that all critics agree upon, namely that Cynthia stands for Queen Elizabeth I.
Cynthia, like all the royalty figures in Lyly's plays, is portrayed as a perfect magnanimous character. The portrayal of the ideal and clement monarch is necessary for Lyly's interest in arousing people's respect for the queen and the established social order under her rule. To achieve this goal, the playwright depicts a group of static characters who do not grow or change like round characters in tragedies and arranges them in a hierarchical social order in which Cynthia occupies the top place. The stasis of the characters in Endymion inevitably results from the lack of a dramatic plot. The playwright does not engage his characters in a course of events that are pushed forward through the laws of probability or cause-andeffect articulation. Instead, the whole play is structured around the riddle of the queen, and her equivocal and paradoxical nature. The writer explains her riddle in Act $\mathrm{V}$, revealing that Cynthia is of dual nature. She is mortal and immortal, earthly and divine. Her ideal world is shown to be the real world, whereas the world of the anti-royal characters is unreal. In the end, these characters quit their malevolent deeds and join Cynthia's orderly and harmonious worldview.

Endymion furnishes much talk and little action. The dialog delays the conclusion rather than develops the action. For instance, Endymion soliloquizes for two acts on his love; Cynthia enters only in Act III when Endymion is asleep;only in Act V the hero and heroine meet awake; Euminedes and Semele are coupled towards the end of the play, while previously their love is only talked about; and Sir Tophas speaks a lot but does nothing. The only narrative in the play is Tellus' scheme against Endymion, and Eumenides' effort to rescue him. These events do not deserve the label of a plot because they have the limited dimension of anecdotes that do not develop from an exposition to a climax and finally to a denouement, according to the Aristotelian tradition that was adhered to in the Renaissance.

Tellus' scheme against Endymion is a threat to the stability and harmony in Cynthia's court. Tellus tries to regain the love of Endymion, who aspires to transcend his mortal status by gaining the love of the immortal Cynthia. In court drama, the ambition to climb the social ladder is considered a threat to the established order. However, Endymion's quest for social mobility is different. He insists that he is a genuine admirer of the queen and not a conspirator against her. He assures her that

I am none of those wolves that bark most when you shinest brightest, but that fish (thy fish, Cynthia in the flood of Araris) which at thy waxing is as white as the driven snow, and at thy waning as black as deepest darkness. *(II, i, 133) 
Endymion identifies Cynthia with the moon, which in her "waxing" and "waning" affects his life like ebb and flood. These two lunar images have political connotations. Waxing is the state of victorious Cynthia over her enemies in England and abroad, whereas waning is the state of Cynthia burdened with political and financial problems at home and beyond borders. Her given state reflects on Endymion's happiness or sadness.

*John Lyly's Endymion, D.Bevington, ed.,(1996), Manchester: Manchester University Press. All quotations from the play will be from this edition and citation will be put in brackets after the quotations.

Endymion's aspiration for transcendence is later encouraged and granted Cynthia's "favor." In contrast, she thwarts the aspirations of Tellus, Dipsas, and Semele. Tellus tries to thwartEndymion'slove of Cynthia. Yet failing in this regard, she resorts to the sorcery of Dipsas and saying: "It was good, Eumenides, that you took a nap with your friend, for your speech beginneth to be heavy" (II, iii, 193).

The antagonistic characters Tellus, Dipsas, and Semele are congregated in a malevolent axis that isresponsible for the temporary disorder in Cynthia's kingdom. This alliance of evil is opposed to the benevolent immortal force of Cynthia and the harmonious world she maintains. The victory of the royal figure, however, lies in her ability to reorder her world in a way that everybody fits in the established order and becomes satisfied with their position. Within this scheme, the only characters who develop and change are the members who compose the wicked group. These three females are the only round characters. However, they arefinally cleansed of their malevolent intentions and practices and join the reestablished order of Cynthia's world. The amelioration of these characters is pivotal for securing harmonious social integrity under the leadership of the guardian monarch.

Lyly's task of creating static yet lively characters with the absence of a sequential plot is achallenging one. Instead of engaging the characters in the action of a complicated plot, he depicts them through speech more than through action. In view of the limited number of events in the play, they are portrayed mainly through the traditional method of speech, and less attention is given to the traditional means of characterization through action.Relevant to characterization through speech, Lyly depends heavily on self-portrayal in soliloquies. Furthermore, the playwright utilizes the indirect method of characterization through juxtaposition. He plays the characters and their traits against each other by way of emphasizing their morality and ethics. Finally, Lyly uses a unique method of characterization byplacing the characters in a hierarchy of perfection, beginning with Cynthia and down to Bagoa as a technique most appropriate for a court play. Furthermore, Lyly resorts to the method of selfportrayal through soliloquy which is given enough room in the play.

Saccio (2016) and Bryant (1956) touch lightly upon Lyly's character portrayal techniques because they direct their attention to interpreting the play as an allegory. Andreas Uschald (1957) deals with some characters in the play as stock characters, considering that as a part of an Italian tradition of character delineation handed down to English writers. This paper aims to discuss the foregoing methods of character depiction employed by the Elizabethan playwright.

\section{CHARACTERIZATION THROUGH SPEECH}

Generally speaking, what characters say reveals a great deal about them. Fred Millet $(1950,17)$ argues the character's opinion of himself, whether precise or excessive, prejudiced or impartial is revealed by his utterance. He adds that dialog discloses the character's opinion of other characters and consequently sheds light on his/her judgment and intelligence. Besides, Millet points out that the character's speech provides insight on his/her scale of values whether he/she is egocentric, selfless, unrealistic, realistic, ethical, or wicked. Furthermore, he/she maintains that utterance also reveals what values comprise his life goals and whether these life goals are materialistic or sensible, self-centered or selfabnegating, and shallow or profound.

Through self-characterization-through-speech Endymion reveals a lot about himself in his dialog with his friend Eumenides. In that exchange, he is shown to be extravagant and ambitious. His affections are

So staid, and withal so stately that I can neither satisfy my heart with love, nor mine eyes with wonder. My thoughts, Euminedes, are stitched to the stars, which, which being as high as I can see, thou mayst imagine how much higher they are than I can reach. (I, i, 183)

Endymion's utterance demonstrates that he is perplexed, confused, and uncertain about the results of his pains. He also appears imaginative and unrealistic, though persistent, about his love for someone beyond the human sphere. The first impressions we get about Endymion are restated and emphasized in Act II:

Will labors, patient of all extremities, obtain thy love? There is no mountain so steep that I will not 
climb, no monster so cruel that I will not tame, no action too desperate that I will not attempt. (II. i. 188)

Endymion's love aspirations are supported by a Herculean spirit and remarkable persistence. He asserts that he is honest and loyal to Cynthia "being always as free from imagining ill as enterprising” (II. i. 189).

In contrast, his attitude toward Tellus is a different one. He only pretends that he loves herbut, in reality, he utilizes her as a cloak for his real affections toward Cynthia. He confesses that

With Tellus, fair Tellus, have I dissembled, using her but as a cloak for mine affections, that others, seeing my mangled and discovered mind, might think it were for one that loveth me, not for Cynthia, whose perfection alloweth no companion nor comparison. (II.i.189)

His pretended affection for Tellus is merely a mask to hide his real love of Cynthia. To Tellus, he admits that "Cynthia I honor in all humility, whom none ought or dare adventure to love, whose affections are immortal, and virtues infinite" (II. i. p, 190).

In a later soliloquy, Endymion lays a comparison between Cynthia and Tellus. The latter is fair, wise, honorable, and fortunate, but without majesty. It is Cynthia's majesty that makes the difference. Of Cynthia, he says: "Thy majesty, Cynthia, all the world knoweth and wondereth at, but not one in the world that can imitate it or comprehend it" (II.iii. 192). This is why Endymionaspires to love Cynthia and why he shuns Tellus. The equivocation of Cynthia'smortal and immortal nature evades understanding.

Self-portrayal is also an effective device in the case of Tellus. In answer to Floscula's statement that Tellus is no match for Cynthia, she admits:

Is not my beauty divine, whose body is decked with fair flower, and veins are vines, yielding sweet liquor to the dullest spirits; whose ears are corn, to bring strength; and whose hairs are grass, to bring abundance? Doth not frankincense and myrrh breath out of my nostrils, and all the sacrifice of the gods breed in my bowels? Infinite are my creatures, without which neither you nor Endymion nor any could love or live. (I.ii. 185)

These words express Tellus' defensiveness about her beautyand virtue. She identifies herself with the Greek deities Dionysus and Demeter and considers herself the fountain of life and love for both mortals and immortals. By giving her this self-image, Lyly skillfully prepares us to see a character who has the potential to challenge the established social order of Cynthia. Tellus' pretentiousness is neither governed by "rule nor reason" (I.ii. 185).

However, towards the end of the play, when Tellus realizes the futility of her pains against Cynthia and Endymion, she confesses her real motive and gives a more humble and accurate appraisal of herself:

I ... fell into this unnatural hate; for, knowing your virtues, Cynthia, to be immortal, I could not have the imagination to withdraw him; and, finding my own affections unquenchable, I could not carry the mind that anyone else should possess what I had pursued. (V. iii. 212)

These late confessions added to earlier dissemblance demonstrate how inaccurate and irrational Tellus is. Her speeches all through the play partially formulate her character and put her against Cynthia, the sovereign figure.

Cynthia's character, too, is partially delineated through self-portrayal. As she bows to kiss Endymion, she says:

I will not be so stately, good Endymion, not to stoop to thee good; if thy liberty consist in a kiss from me, thou shalt have it. ... I will do that to Endymion which yet never mortal man could boost of heretofore, nor shall ever hope for hereafter. (V. i. 206)

Lyly establishes the figure of Cynthia as stately sovereign. She is unattainable to human love. However, her kiss of Endymion is shown not to be an amorous act, but a lifegiving gesture. She doesn't hesitate to save anyone of her subjects who suffers the magic deeds of the anti-royal characters. For instance, she promises to recover Bagoa from transmutation "if in my power be the effect of the truth" (V. iii.107), the same way she rushes to save Endymion from the forty-year slumber inflicted upon him by Dipsas under the instructions of the jealous and revengeful Tellus.

In portraying the character of Cynthia, Lyly resorts to the indirect method of characterization throughspeech. She does not talk of herself but is depicted through the utterances of other characters. They recognize her authority, power, and mercy. From Gyptes, the Egyptian soothsayer, for instance, acknowledges that truth and virtue are everyday practices of her court: "They are thrice fortunate that live in your palace where truth is not in colors but life, virtues not in imagination but execution" ( IV, iii; 204).Truth in Cynthia's palace refers to the absence of falsehood in her world. She has the ability to uncover and countermand conspiracies and evil deeds. Virtues in her world refer to her justice and mercy that leave everyone in her monarchy satisfied and happy. 
Cynthia can put into practice what seems to the shortsighted philosophers to be imaginative and ideal. In Act IV Cynthia is cynical of the preposterousness of Pythagoras,' ideas about the transmigration of souls. "[Y]ou see, Pythagoras, what ridiculous opinions you hold," says Cynthia (IV. iii. 204). In his turn, Pythagoras confesses that he is illuminated by the glare of Cynthia's perfect mind: "Madam, I plainly perceive that the perfection of your brightness hath pierced through the thickness that covered my mind; insomuch that I am no less glad to be reformed than ashamed to remember my grossness"(IV.iii. 204).Later, Cynthia invites Pythagoras and Gyptes to join her court on the condition that they give up the vain follies of their philosophy and adopt the virtuousness and truthfulness of her court.

Endymion's comments on Cynthia also contribute other traits to her character, namely her divinity and unattainability. He complains to Eumenides:"My thoughts, Eumenides, are stitched to the stars, which, being as high as I can see, thou mayest imagine how much higher they are than I can reach (I.i. 183).Moreover, he asserts these aspects of divinity and immortality in Cynthia's character in his first encounter with Tellus $(11, \mathrm{i})$.He says, "Cynthia I honor in all humility, whom none ought or dare adventure to love, whose affections are immortal, and virtues infinite " (II.i. 190).In addition, he emphasizes the fact that Cynthia changes only as a body, yet her soul she is ever constant and "ever ... unmovable" (I.i. 184).

Floscula, too, admits Cynthia's transcendence above mortal life. She holds that Cynthia is "more than mortal, "and"governeth all things" (I. ii. 185). Besides, she recognizes, as well, that Cynthia is the fountain of life and the source of order:

Your grapes would be but dry husks, your corn but chaff, and all your virtues vain, were it not Cynthia that preserveth the one in the bud and nourisheth the other in the blade, and by her authority commandeth all creatures. (I. ii. 185)

These comments on Cynthia refute Tellus' pretensions that she masters all life. Tellus admits that by loving Cynthia, Endymion is fixing his thoughts the unattainable. And Geron, in his argument with Eumenides, describes Cynthia as the most absolute of all circles. We can notice how Lyly portrays the character of Cynthia as an unattainable transcendent force and a magnanimous monarch through the comments and confessions of others, not excluding her antagonistic adversaries. Using this method Lyly establishes some of the main traits of Cynthia's character, namely, divinity, unattainability, mercy, justice, truth, and life-giving power. This technique in the end facilitates
Lyly's task to compliment the queen and delineate her as a perfect character.

This technique, however, is not only used to delineate Cynthia's character; but todepict every other character in the play. As an example, I shall discuss other characters' comments on Endymion to show how these comments contribute to the construction of his character. Eumenides, for example, describes him as"a man of such rare virtues" (I. i. 184). Floscula admires his ambition and wonders at "the greatness of his mind, being affected with a thing more than mortal" (I. ii. 185). Later, Cynthia describes him as a "gentleman" who "once vowed all to my service."She has favored him "for thy honor, thy virtues, thy affections" (IV. Iii.204). Nevertheless, Tellusis ambivalent about him. Sometimes she calls him "treacherous and most perjured Endymion" (I. ii. 185), other times she refers to him as a "sweet person" (I. ii. 185), and later she speaks about "the sweet face of Endymion"(IV.i. 200). Tellus's divided attitude toward Endymion can be understood with references to her confession about her motives, being "a woman deluded in love to have neither rule nor reason" (I.ii.185). She is completely driven by her anguish and jealousy, in which case, it is necessary to take her judgment on Endymion or others with a grain of salt.

However, her judgment of other characters can be more indicative of her character. She appears far from being balanced and reasonable. She evaluates others based on her blinding erroneous and blind jealousy. In her rage, she commits horrendous actions which she regrets in the end when she gives up her wicked course of action after she realizes the futility of her attempts to regain Endymion and suffices with what she gets within the hierarchy of Cynthia's world.

In contrast, Euminedes' judgment on Endymion that he is "a man of such rare virtues there could not harbor a mind of such extreme madness" (I.i. 184) does not indicate that Endymion is mad, rather it shows a realistic person commenting on his idealistic friend who is not satisfied with any love below the moon.

Generally, the comments of one character on another enable the playwright to establish the traits of the second character and, simultaneously, shed light on the speaker himself, his judgment, whether partial or impartial, objective or subjective. Besides, what a character says reveals his/her scale of values; whether selfish or altruistic, idealistic or realistic, moral or immoral. It also helps the playwright express the person's life goals being realistic, self-regarding, superficial, or profound since he cannot express these life goals or the scale of values directly the way a novelist or a poet does. For example, in reaction to the dilemma of Endymion, Cynthia argues that she has 
"studied to have rather living virtues than painted gods, the body of truth rather than the tomb" (IV. iii. 204), and encourages Endymion to pursue his love aspirations toward her: "Persevere, Endymion, in loving me, and I account more strength in a true heart than in a walled city" (V. iii. 212). Simultaneously, she strictly threatens Tellus and Semele, saying:

I will tame your tongues and your thoughts, and make your speeches answerable to your duties, and your concerts fit for my dignity, else will I banish you both my person and the world. (II. iii. 193)

These utterances and views reveal Cynthia's scale of values. She is delineated as a perfectionist who is concerned with truth and virtue. In the judgment scene, Lyly reveals Cynthia as an altruistic character who derives happiness from the contentment and satisfaction of her subjects.Lyly also utilizes the utterances of Eumenides to establish his scale of values and life objectives. Eumenides appears realistic and cannot understand his friend Endymionin his attempt to love an immortal being. He is also a loyal friend as we learn from his argument with Geron in which he shows a deep understanding of the value of friendship which he prefers to love.

The playwright uses another form of utterance, namely soliloquy as a medium of characterization to present the thought processes of the speakers directly to the audience. He utilizes the dramatic convention to guide the audience into the innermost depths of his characters. There are seven soliloquies in Endymion: two by Endymion (II.i.188; II.iii. 192), two by Tellus (IV. i. 200; IV. i. 201), one by Eumenides (I.i. 184), one by Corsites (IV. iii. 203), and one by Bagoa (II. Iii. 193). To elaborate on Lyly's use of soliloquy as a means of characterization, this study elaborates on the soliloquies of Bagoa and Corsiteswho have not been dealt with so far.

Bagoa's soliloquy does not only reveal her goodness, but rather discloses a lot aboutthe characters of Endymion, Dipsas, and Tellus. Her benevolent nature is indicated by her hesitation to fan hemlock on Endymion's face upon the orders of Dipsas. Yet she has to do it due to her fear lest the sorceress transmutes her into a pine tree. In addition, we realize the superficiality of her life goal, i.e. to get married. Her fear and worries are substantiated towards the end of the play. Dipsas transmutes her into a tree, but she is promised to be liberated and married to Sir Tophas.Bagoa's speech also contributes to Endymion's characterization as a fair man and virtuous person.

Corsites' soliloquy portraysa character of a militant figure who is weakened by love. He used to be a very powerful soldier. He did once "pull up a tree that forty years was fastened with roots and wreathed in knots to the ground," and let "open the iron gates which no ram or engine could move." Furthermore, his speech describes the state of Endymion, who has become very heavy in his sleep that he appears to be "nailed to the ground." If we put his attitude toward Tellus within context, then weunderstand that he is irrational, naïve, and gullible. His speech, therefore, portray his character and sheds light on Endymion and Tellus.

\section{CHARACTERIZATION THROUGH ACTION:}

In delineating his characters, Lyly also uses the technique of characterization through action. However, this method is not as effective as characterization through speech simply because the play does not have an elaborate plot. Only few events occur in the play. These events include Tellus' revenge upon Endymion for cheating her, Dipsas' transformation of Bagoa into an aspen tree because she releases the secret of Endymion's whereabouts, Eumenides' visit to the enchanted well and discovery of a solution for his friend's endless sleep, Geron's assistance of Eumenides to understand the puzzle of the well, Cynthia's hard effort to save Endymion and her acceptance to bend humbly and kiss him to reawaken him and restore his life, and Cynthia's reconciliation of the characters in reasonable arrangements of marriage at the end of the play. All these incidents are off-shoots of the central event of Tellus putting Endymion to sleep till the end of his days. These anecdotes, however, cannot furnish the play with an elaborate plot like the ones we see in Shakespeare's and Marlowe's plays.

The jealous Tellus revenges upon Endymion for betraying her to love Cynthia. She is given enough room to explain her grievance to Cynthia. Her problem is the disproportionate revenge she inflicts upon Endymion to put him to a ceaseless sleep till Cynthia awakens him after forty years. In order to do that she resorts to the black sorcery of Dipsas who puts him in a state between death and life so that he sleeps his youth and gets old and paralyzed. This action is utilized to portray the viciousness, maliciousness, revengefulness, destructiveness, and psychological morbidity of Tellus. Under jealousy, she behaves blindly, outrageously, recklessly, and disproportionately. She betrays her class and gender expectations and, in the end, she is deprived of Endymion's love. Cynthia rebukes her for her numerous monstrous mischiefs in her young age:

But tell me, Tellus, what was the cause of this cruel part, far unfitting thy sex, in which nothing should be but simpleness, and much disagreeing 
from thy face, in which nothing seemed to be but softness? (5.4. 38-39)

Her heinous crimes reflect her instability and defensiveness and do not become her gender.

Dipsas' practice of black magic characterizes her as a malevolent sorceress, who allies with Tellus and deprives Endymion of his youth. Her malignance and horrendous evil are further multiplied as she transforms Bagoa into an aspen tree in punishment for releasing the location of the slumbering Endymion. This is why Cynthia sentences her to depart the human community to live among the beasts where she best fits. Says Cynthia:

And as for you, Dipsas, I will send you into the desert amongst wild beasts, and try whether you can cast lions, tigers, boars, and bears into as dead a sleep as you did Endymion, or turn them to trees as you have done Bagoa. (V.4. 48-52)

The efforts of Eumenides to save Endymion demonstrate his genuine fabric as a friend indeed. When given the choice between sustaining the love of Semele and redeeming his friend Endymion, he chooses to save his friend despite his deep affection for Semele. He is shown to value friendship and is constant in love for Semele despite her notorious behavior and rejection of his affection.

In contrast to Tellus and Dipsas, Cynthia is characterized as a life-giver in saving Endymion's life and rejuvenating him. And despite her unattainable nature, she encourages Endymion to continue his love for her. In addition, coupling her subjects at the end of the play and taking all measurements to guarantee the happiness and security of each member in her world, assures the audience of her as a benign force of harmony and stability. She matches Tellus to Corsites, Semele to Eumenides, Dipsas to Geron, and Bagoa to Tophas. These couples are satisfied and align to the code of conduct set by the divine sovereign.

Along with the depiction of characters by means of what they say and what they do, Lyly resorts to two other techniques, namely juxtaposition, and hierarchal arrangement. He puts the characters against each other or pairs them in an alliance so that they enrich each other's traits.

\section{CHARACTERIZATION THROUGH JUXTAPOSITION}

In Endymion, the characters gather attributes from juxtaposing them with other characters on the mythological orpoliticalallegorical levels which are intertwined in the play. Whatever allegorical interpretation the play takes, the characters gather attributes by being played against one another. For instance, Tellus, the goddess of the Earth is contrasted to Cynthia, the Goddess of the Moon in the mythological allusions of the play. Tellus and Floscula are also allegorical figures for Lady Sheffield and Lady Essex the two wives of Leister (Endymion), and are juxtaposed to Cynthia (Queen Elizabeth I) in the political interpretation of early critics Baker (1894) and Schelling(1910).

Kubra Vural in an insightful article studies opposing elements in the play as a process of reconsolidating" antithetical forces in an array of conflicts [that] create unison of multiple perspectives in such works" (p. 1). Vural maintains that conflict is necessary for drama to keep the action running and sustain suspense and curiosity. Conflict, she adds, is the "substance that creates the drama" (Knox, 2009, 132, cited in Vural 2016). Renaissance playwrights created rhetorical patterns by reconciling antithetical dual sets. Vural (2016) rightly argues that John Lyly constructs Endymion upon binary opposites that create the conflict and reconcile at the end of the play. The antagonistic pairs in the play enhance the non-conventional method of characterization through juxta position. Juxtaposition is a natural outcome of the different natures of the conflicting characters in the play. Most evident is the juxtaposition between Cynthia and Tellus. What dictates the contrast between them is the love of Endymion, who aspires to attain the love of Cynthia and dissembles that he loves Tellus. As the latter discovers Endymion's betrayal of her love and his longing to attain the affections of Cynthia, she has no choice but to contrast herself to Cynthia.

In the opening dialog in the play, Endymion confides to Eumenides that his real affection is devoted to the divine Cynthia and is only dissembling that he loves Tellus. The dialog strikes a comparison between the two. The one is divine and empowered by the deities of heaven, the other is terrestrial and human, one is immortal, the other is mortal. That juxtaposition serves as an effective and revealing method of characterization.

Similarly, in Act 1, scene 2, the angry Tellus in an exchange with Floscula defensively lays the contrast between herself and Cynthia:

No comparison, Floscula? And why so? Is not my

$\cdots$

beauty divine, whose body is decked with fair flowers, and

veins are vines, yielding sweet liquor to the dullest spirits, 
Whose ears are corn to bring strength, and whose hairs are

grass to bring abundance? Doth not frankincense

and sacrifice of

myrrh breathe out of my nostrils, and all the

the gods breed in my bowels? Infinite are my creatures,

without which neither thou nor Endymion nor any could

love or live.(1.2.20-28)

In her defense, she portrays herself as a goddess of the earth who gives life to all creatures, to which Floscula replies:

But know you not, fair lady, that Cynthia

governeth all things? Your grapes would be but dry husks, ...

your corn but chaff, and all your virtues vain were it not

Cynthia that preserveth the one in the bud and nourisheth

the other in the blade, and by her influence both comforteth

all things and by her authority commandeth all creatures.(1.2. 29-34)

Floscula points out that Cynthia governs everything and without her, nothing can be preserved, and no life can be fulfilled. She commands all creatures, including Tellus. Later when she tries to justify to Cynthia her atrocity of putting Endymion to enchanted sleep, she confesses her humbleness to the divine Cynthia in "majesty, beauty, virtue, and dignity" (5. 4. 134).

In a soliloquy in the lunar valley, Endymion juxtaposes the two showing that both Cynthia and Tellus share the tributes of beauty, wisdom, honor, and fortune. What distinguishes Cynthia, however, is her majesty. He explains:

O Endymion, Tellus was fair! But what availeth

beauty without wisdom? Nay, Endymion, she was wise. But

what availeth wisdom without honor? She was honorable,

Endymion, belie her not. Ay, but how obscure is honor

without fortune? Was she not fortunate whom so many followed? Yes, yes, but base is fortune without majesty. Thy

majesty, Cynthia, all the world knoweth and wondereth at,

but not one in the world that can imitate it or comprehendit. $(2,3,13-20)$

In this regard, Saccio (2016)holds "Cynthia and Tellus clearly offer to Endymion higher and lower kinds of love, rapt adoration of a goddess or pursuit of ordinary earthly beauty" (173). The contrast between the two characters is established on three bases, namely actions, values, and social status. Tellus puts Endymion to sleep, while Cynthia brings him back to life. Tellus is selfish, revengeful, and cruel, while Cynthia is altruistic, merciful, and just. Cynthia is a goddess and a queen on earth, Tellus is merely an anti-royal character who is finally coupled to one of Cynthia's soldiers. An important part of Lyly's juxtaposition is based on the technique of alienation of the anti-royal figures Tellus, Dipsas, and Semele.

Furthermore, Endymion is also juxtaposed to Cynthia. He is human and belongs to the transitional sphere of earth, whereas Cynthia is immortal and belongs to the lunar sphere. Like Cynthia, Endymion is a human being and his affection for her is described by Eumenides as ridiculous.Eumenides:

If you be enamored of anything above the moon, your thoughts are ridiculous; for that things immortal are not subject to affections. If allured or enchanted with these transitory things under the moon, you show yourself senseless to attribute such lofty titles to such low trifles. (1. 1. 9-11)

The contrast here is between the mortal and immortal, the mutable and constant, the ephemeral and eternal.

The other character who is juxtaposed to Cynthia is the enchantress Dipsas. Khomenko (2010) contends that despite distancing the basis of the play by choosing a classical tale of Endymion, he maintains the interest of his audience by referring to the contemporary debate on magic, witches, and witchcraft made available in the character of the sorceress Dipsas, her malevolent practices, and limitations compared to the divine majestic power of Cynthia. Dipsas' malicious abilities are put in the service of the revengeful Tellus by enchanting Endymion to a state between life and death, and transforming her assistant Bagoainto an aspen tree for releasing the secret of the location of Endymion. These practices upset the natural order which is regained by the life-giver and healer Cynthia. The juxtaposition of Cynthia's benevolence and Dipsas' malevolence overemphasizes the opposite features 
of both characters as they are played against one another. Besides, the avid atrocities of the Dipsas show her power over people, but Cynthia's rehabilitation of the social and natural order demonstrates her majestic power juxtaposed to Dipsas' fake and artificial enchantment.

This technique of juxtaposition includes other characters.Tellus, for instance, is contrasted to her maid and assistant Floscula. They disagree on everything. Floscula has a high opinion of Endymion and recognizes the immortality and authority of Cynthia, whereas Tellus has a different opinion or rather tends to have one.

In contrast, the pro-royal characters namely, Endymion, Eumenides, Floscula, Bagoa, and Geron are all in league with Cynthia. The juxtaposed characters enrich each other's features. Tellus' self-interest is deepened when contrasted to Endymion's readiness to sacrifice himself for the sake of Cynthia, or Eumenides' choice of Endymion's friendship over Semele's love. Eumenides' realism is brought to light being put against Endymion's idealism.

\section{CHARACTERIZATION THROUGH SOCIAL POSITIONING}

The fourth method of characterization Lyly uses in the play is arranging the characters in hierarchical order in which the monarch occupies the highest rank. The play stratifies the characters into two spheres: lunar and terrestrial. In the lunar sphere is Cynthia, who is constant, virtuous, clement, constructive, unprejudiced, and is supported by divine forces. She is immortal and gives healing to the characters in need. Her beauty is alluring but unattainable. She is in control of the terrestrial sphere and heals enchanted characters from the charms of deprived forces of witchcraft and the linguistic aggression of rude tongues. She reconciles characters and places them in a stratified order in which everybody is contented and satisfied. Her reconciling the characters in married couples guarantees successful and peaceful social concordance.

On the terrestrial level, the characters fall within categories of social classes according to their amorous aspirations and practices. All the characters are classed out according to their love attachments, detachment, and schemes to attract or revenge upon others. Characters include both males and females that are relegated to upper class, middle class, and lower class. Evidence of their allocations is relevant to their conduct regarding love. Among the upper-class characters, Endymion is isolated and relieved from the terrestrial human love of Tellus as he aspires to love Cynthia. However, Cynthia's love is unattainable, and Endymion is encouraged by being given Cynthia's favor. He suffices to live in adoration of her. As an upper-class person, he gathers attributes that belong to his class. These tributes include decency, honesty, and constancy in friendship. He, however, is different from the other characters of the same rank in his aspiration to love the unattainable Cynthia in her lunar superior sphere. This ambitious endeavor raises the astonishment of his dear friend Eumenides:

If you be enamoured of anything above the moon, your thoughts are ridiculous, for that things immortal are not subject to affections ; ifallured or enchanted with these transitory things under the moon, you show yourself senseless to attribute such lofty titles to such lovetrifles. (1.1.8-12)

This overreaching love of Endymion, however, is encouraged and approved by Cynthia.

Endymion, this honorable respect of thine shall be christened love in thee, and anyreward for it, favor. Persevere, Endymion, in loving me, and I account more strength in atrue heart than in a walled city.... Endymion,continue as thou hast begun, and thou shalt find that Cynthia shineth not on thee in vain. (5.4.171-180)

This endorsement of Endymion's love elevates him to a sublunary mythical status which is lower than the moon but above the human sphere.

Eumenides is "of honorable birth, honest manners, and true love" (5.4.220) is an honest and constant friend and lover. These are attributes of his layer in the social order of Cynthia's world. These include friendship and constancy in love. Eumenides demonstrates his constancy as a friend in the fountain scene when he is given the chance to have one wish. He is divided between reconciliation with his long-tongued Semele and saving his friend from dormancy. Dipsas puts Endymion upon the order of the jealous Tellus to 40 years of sleep. He sacrifices his personal interest in regaining Semele's love to save his friend back to wakefulness and youth. Through the agency of the divine Cynthia, he regains his friend to life again and is rewarded with the reunion to Semele after her behavior has been refined by Cynthia.

Semele consents to get married to Eumenides:

I am content Your Highness shall command, for now only do I think Eumenides faithful, that is willing to lose his tongue for my sake; yet loath, because it should do me better service. Madam, I accept of Eumenides. (5.4.233-37) 
Tellus and Semele are also two upper-class ladies. They, however, morally deteriorate from their status through their destructive conduct, sharp tongues, and abusive language. The jealous Tellus with the help of the enchantress Dipsaspunishes Endymion and puts Corsites in a weird situation when she sends him to remove Endymion from his place. Tellus is beautiful, yet her beauty is smeared by her arrogance. She is also irrational as her revenge upon Endymion is out of proportion. Cynthia sums up her story:

Is it possible, Tellus, that so few years should harbor so many mischiefs? Thy swelling pride have I borne because it is a thing that beauty maketh blameless, which, the more it exceedeth fairness in measure, the more it stretcheth itself in disdain. Thy devices against Corsites I smile at, for that wits the sharper they are, the shrewder they are. But this unacquainted and most unnatural practice with a vile enchantress against so noble a gentleman as Endymion I abhor as a thing most malicious, and will revenge as a deed most monstrous.(5.5.40-47)

Cynthia recognizes the extreme earthly beauty of Tellus which can understandably lead to arrogance. But her malicious revenge is abnormal and malicious. In the end, Tellus recognizes her deviation and apologizes to Cynthia and Endymion. She reconciles to society and joins the social order of Cynthia's world as a wife to Corsites because she finally realizes the futility of her attempts to regain Endymion's affection.

Semele is another sharp-tongued upper-class lady. She allies with Tellus against Endymion and shuns her lover because he sympathizes with Endymion. He regains her love at the end as she realizes his loyalty when he expresses his willingness to ransom Semele's tongue with his own.Characters are re-allocated to their status and consent to abide by the social protocol established by Cynthia.

Lower-class characters, especially the vulgar braggart Sir Tophas, are shown to be crude, careless, and idle. Sir Tophas serves as a clown for a group of servants and the pages. Even these characters have their place in the hierarchal society of Cynthia. Sir Tophas is satisfied by his marriage to Bagoa after being releasedfrom the enchantment ofDipsas. The latterdeteriorates from the human order to a devilish status. She employs her vicious art to disturb the social order of Cynthia. Her heinous actions are countermanded by Cynthia. The clement ruler accepts Dipsas' apology and espouses her to Geron, the wise sage who guides Eumenides to the solution of Endymion's problem. These newly arranged characters are to start a new course of action in a Cynthia world which allows only for true and virtuous practices.

\section{CONCLUSION}

Lyly succeeds in giving life to static characters even in the absence of an elaborate plot. Action in the play, however, is carried forward through a court scheme motivated by the anti-royal character Tellus, with the help of the sorceressDipsas. The playwright succeeds in paying the queen a flattering compliment which is the only thingone can be sure about in the interpretation of the Endymion. Lylyis successful in almost pluckingout the heart of his characters' mysteries through what they say, do, and through juxtaposition, and through arranging them in a hierarchical social order.

The methods of portraying characters through speech and action are in line with the traditional techniques of character depiction in Elizabethan drama. However, the methods of characterization through juxtaposition and social positioning are remarkable in this play. They are not unique in Endymion, but they are given more importance here than anywhere else in the Renaissance. The play marches forward by the tension created by the struggle of antithetical binary forces. This structure of the play emphasizes the tributes characters import from contrasting with their opposite counterparts.

Besides, the play converges with the Elizabethan view of the stratified structure of society and the universe at large.John Lyly utilizes this perception to class out his characters into categories. These categories convey tributes that are endowed upon the characters without their doing or saying anything that purports to these tributes. This technique distinguishes this play from the traditions of character depiction in Elizabethan drama.

\section{REFERENCES}

[1] Berry, P. (2017). Of Chastity and Power: Elizabethan Literature and the Unmarried Queen. London: Routledge.

[2] Bevington, D. ed. (1996). John Lyly's Endymion. Manchester: Manchester University Press. All quotations from the play will be from this edition and will be put in brackets after the quotations.

[3] Bozio, A. (2016). The Contemplative Cosmos: John Lyly's Endymion and the Shape of Early Modern Space. Studies in Philology, 113(1), 55- 81

[4] Deats, S. (1975). The Disarming of the Knight: Comic Parody in Lyly's "Endymion". South Atlantic Bulletin, 40(4), 67-75. doi: 10.2307/3199121

[5] Hunter, G. (1962). John Lyly. London:Routledge \& Kegan Paul. 
[6] Khomenko, N. (2010) 'Between You and Her No Comparison': Witches, Healers, and Elizabeth 1 in John Lyly's Endymion. Early Theatre 13, 1, 37-63.

[7] Knapp, R. (1976). The Monarchy of Love in Lyly's "Endimion". Modern Philology, 73(4, Part 1), 353-367. doi: $10.1086 / 390673$

[8] Knoll, G. (2014). How To Make Love to the Moon: Intimacy and Erotic Distance in John Lyly's Endymion. Shakespeare Quarterly, 65(2), 164-179. doi: 10.1353/shq.2014.0017

[9] Lenz, C. (1976). The Allegory of Wisdom in Lyly's Endimion. Comparative Drama,10(3), 235-257. doi: $10.1353 / \mathrm{cdr} .1976 .0026$

[10] McCarthy, J. (2003). Ben Jonson and the Boy Company Tradition. Journal For Early Modern Cultural Studies, 3(1), 1-49. doi: 10.1353/jem.2003.0000

[11] Neufeld, C. (2007). Lyly's Chimerical Vision: Witchcraft in Endymion. Forum for Modern Language Studies, 43(4), 351-369. doi: 10.1093/fmls/cqm060

[12] Saccio, P. (2016). The Court Comedies of John Lyly. Princeton, N.J: Princeton University Press.

[13] Thomas, S. D. (1978).Endymion and Its Sources. Comparative Literature 30,1, 37-8.

[14] Trimikliniotis, N. (2013). Sociology of reconciliation: Learning from comparing violent conflicts and reconciliation processes. Current Sociology, 61(2), 244264. doi: $10.1177 / 0011392112456508$

[15] Vanhoutte, J. (2011). Age in Lust: Lyly's Endymion and the Court of Elizabeth I. Explorations In Renaissance Culture, 37(1), 51-70. doi: 10.1163/23526963-90000401

[16] Vural, K. (2017). A Reconciliation of Conflicts: John Lyly's Endymion, The Man in the Moon. Uluda University Faculty of Arts and Sciences Journal of Social Sciences, 18, 32, 1-14. DOI: 10.21550/sosbilder.298171 